\title{
高速極性切替放電加工に関する研究*
}

\author{
宇野義幸 ${ }^{* *}$ 岡田 晃** 伊藤 満** 高木 俊***

\section{The Effect of High Speed Polarity Changing on EDM Performance}

\section{Yoshiyuki UNO, Akira OKADA, Mitsuru ITOH and Takashi TAKAGI}

\begin{abstract}
Machining performance in the normal polarity EDM greatly differs from that in the reversed polarity one. The removal rate in the normal polarity EDM is high, though the electrode wear is large in EDM with graphite electrode. On the other hand, the removal rate in the reversed polarity EDM is relatively low, though the electrode wear is small, which leads to no electrode wear EDM under a proper machining condition. Therefore, it is considered that it might be more effective to mix both the normal polarity EDM and the reversed polarity one.

In this paper, the effect of polarity changing on the EDM performance with graphite electrode is experimentally investigated, using high speed polarity changing device in which the number and the polarity of discharge can be quickly changed at will, in order to attain higher removal rate and lower electrode wear. Main conclusions obtained are as follows:

(1) The removal rate takes a maximum when the reversed polarity discharge is a little mixed into the normal polarity EDM with kerosine type fluid. It is due to the removal of carbonized layer and/or heat resolved carbon of machining fluid from the workpiece surface.

(2) The removal rate, the electrode wear and the surface finish in EDM with kerosine type fluid depend on the ratio of normal polarity discharge to the reversed polarity one regardless of the number of each polarity discharge in a cycle.

(3) The removal rate in EDM with deionized water increases linearly with increasing the ratio

\footnotetext{
* 1994年度精密工学会春季大会 (平成 6 年 3 月 24 日) にて発表

$* *$ 岡山大学工学部

*** イビデン(株)
} 
Vol.29 No.60

of normal polarity discharge.

(4) The electrode wear and the surface finish in EDM with kerosine type fluid become larger with increasing the ratio of normal polarity discharge.

\section{1. 緒言}

放電加工において工具電極を陰極とする正極性加工と, その逆の工作物を陰極とする逆極性加工と では加工特性が大きく異なる。一般にグラファイト電極を用いて鋼を加工する場合，正極性加工では 加工速度が大きいが, 工具電極の消耗も大きくなる。また, 加工を妨げる要因となる炭素生成物も加 工表面に付着しやすくなる゙。これに対し逆極性加工は加工速度は小さいが電極の消耗は少なく，放 電時間を長くした場合には電極無消耗加工も可能である2)。この極性による加工特性の違いは，主に 陽極と陰極に配分される放電エネルギの違いや加工液の熱分解生成物の付着などに起因するといわれ ている33.4。このように両者の特性は相反するあのであるため, それぞれの欠点は互いの極性を適当 におりまぜることによって改善できるのではないかと推測される。

そこで本研究では, 高速で極性を切り替えることのできる高速極性切替装置を用いて, 加工中に任 意に極性を切り替えた場合の加工特性について実験的に検討を行った。

\section{2. 実験方法}

図 1 は，本研究で用いた実験装置を模式的に示すすのである。実験はトランジスタスイッチング式 のNC放電加工機を用いて行った。工具電極には直径 $10 \mathrm{~mm}$ の円柱状のグラファイトを, また工作物 には冷間金型鋼SKD11を用いた。加工液には, 灯油系加工液（比抵抗 $10^{10} \Omega \cdot \mathrm{cm}$ 以上）およびイオ ン交換樹脂を通した脱イオン水（比抵抗 $10^{6} \Omega$ ・ cm以上）を用いた。なお, 加工中は電極と工作 物間に $4.9 \times 10^{4} \mathrm{~Pa}$ で加工液の噴流をかけた。極 性を切り替えるための回路には高速極性切替装 置 (High Speed Polarity Changer)を用いた。 これは, 放電加工中に加工機の電源装置から出 カされるトリガ信号を取り込み，設定したパル ス数を計数したのち強制的に極性を反転させる

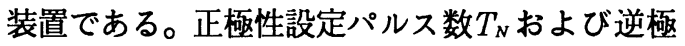
性設定パルス数 $T_{R}$ はそれぞれ 1 から 255 まで任 意に設定することが可能である。

図 2 は高速極性切替装置を用いて放電加工を

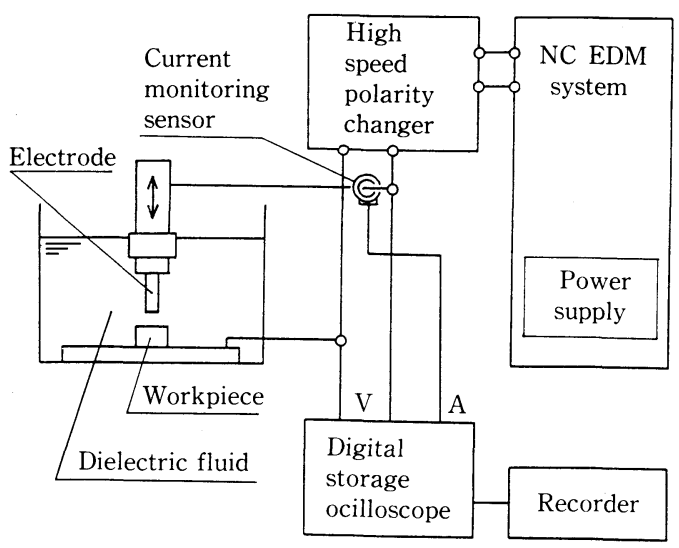

図 1 実験装置模式図 
行った場合の極間電圧および放電電流の湘定例で ある。図は正極性設定パルス数を 3 ，逆極性設 定パルス数を 2 とした場合の波形である。図より 最初に逆極性で 2 回放電が生じた後, 極性が反転 し, 前の放電とは逆の電圧が印加され正極性放電 が 3 回生じていることがわかる。そして,このサ イクルが繰り返されて続いていく。

本実験では, 正極性放電回数の全放電回数に対 する比率を

$$
N=100 \cdot T_{N} /\left(T_{N}+T_{R}\right)(\%)
$$

と表した（この場合 $N=0 \%$ は逆極性加工を，ま た $N=100 \%$ は正極性加工を示す)。ここでは, 正

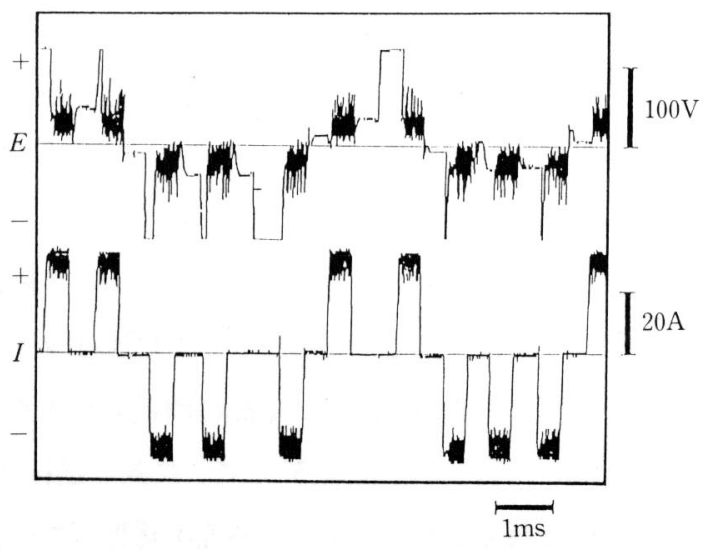

図 2 極間電圧および放電電流波形

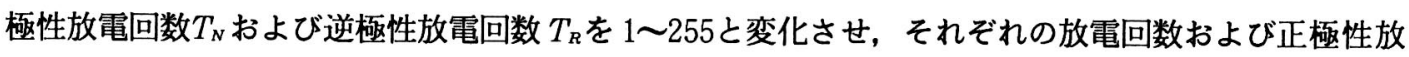
電回数の全放電回数に対する比率 $N$ が加工特性に及ぼす影響について検討した。

\section{3. 実験結果および考察}

\section{1 極性による加工特性の違い}

まず正極性加工と逆極性加工の加工特性の違いを把握するため, それぞれの極性でグラファイト電 極を用いて, 単発放電実験および連続放電実験を行った。

図 3 は, 同一加工条件で 逆極性放電および正極性放 電によって形成された単発 放電痕の電子顕微鏡写真で ある。図より明らかなよう に逆極性の場合, 放電痕の 深さはあまり大きくなく， 工作物はほとんど除去され ていない。また表面は再凝 固した工作物によって覆わ れている。いっぽう正極性 の場合は逆極性の場合より 底の深いクレータとなって

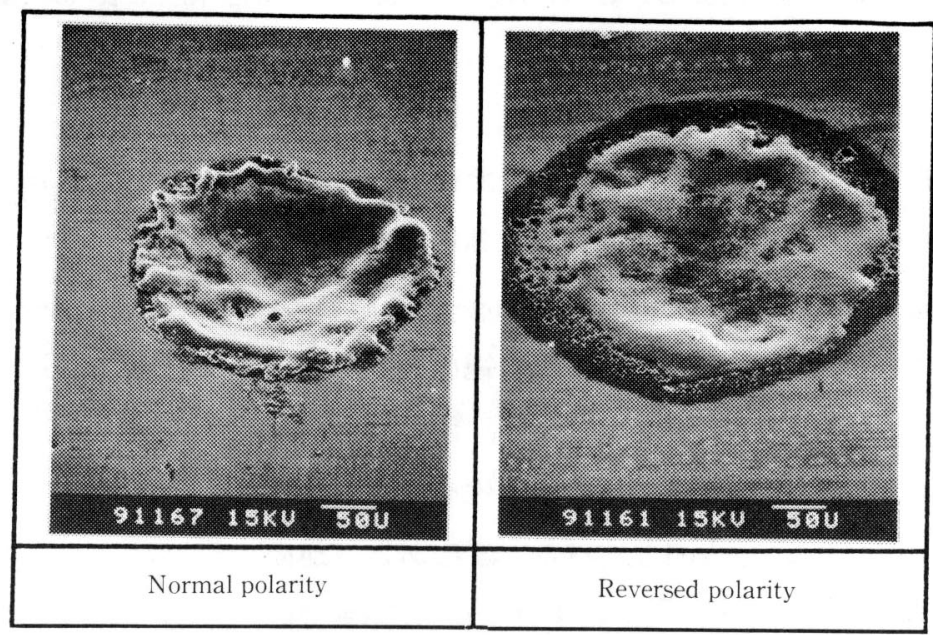

Gr/SKD11, $I_{p}=40 \mathrm{~A}, \tau_{p}=40 \mu \mathrm{s}$, In kerosine type fluid 図 3 極性による単発放電痕の違い 
Vol.29 No.60

おり，逆極性よりあ除去体積は大きいことが わかる。

図 4 は放電電流 $I_{p}=30 \mathrm{~A}$, デューティファ クタ $50 \%$ の条件で放電時間 $\tau_{p}$ を変化させた ときの加工速度 $\dot{R}$ と電極消耗率 $W$ 示すすの である。図中, ○は正極性加工の, ○は逆極 性加工の加工速度を示している。どちらの極 性においても加工速度は放電時間の増加とと あに増加し, $100 \mu \mathrm{s}$ 付近で極值をすつが, 逆

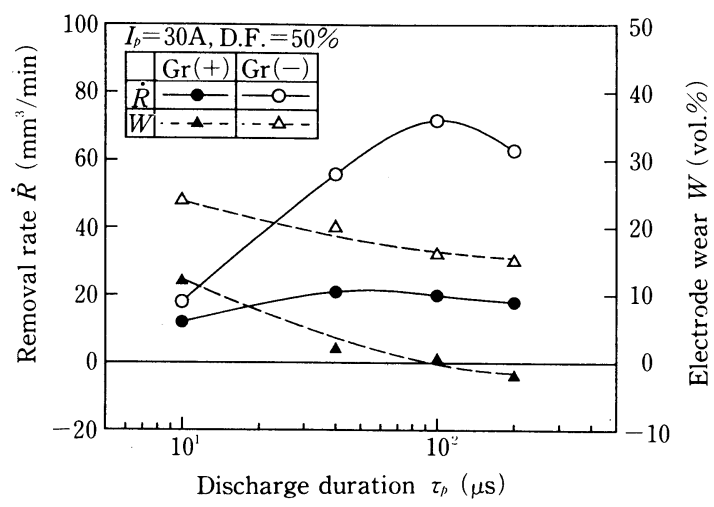
極性の加工速度は正極性の場合の 3 分の 1 か ら 4 分の 1 と非常に小さいことがわかる。ま

図4 極性による加工速度および電極消耗率の違い た， $\triangle$ は正極性加工の， $\Delta$ は逆極性加工の電極消耗率を示している。電極消耗率は両者とも放電時間

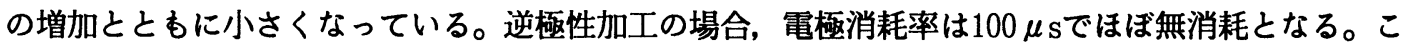
れは放電時間の増加とともに電極端面への加工液の熱分解カーボンの付着量が多くなるためである。 これに対し正極性加工では, $100 \mu \mathrm{s} て ゙ 15 \%$ と非常に大きな值を示している。このように極性による加 工特性の違いは明らかである。一般にこのような極性による放電加工特性の違いは，両極に配分され る放電エネルギの違いによるといわれており，グラファイト電極を用いた場合には，その差は大きい。 図から明らかなように特に放電時間の長い条件で両者の違いはより明確に表れる。そこで以下の実験 では, 放電時間 $\tau_{p}=200 \mu \mathrm{s}$, 放電電流 $I_{p}=30 \mathrm{~A}$ の条件で加工を行った。

\section{2 加工速度}

図 5 は灯油系加工夜中で極性を切り替えて加 工を行った場合の加工速度 $\dot{R}$ 正極性放電回数の 比率 $N$ 関係を示している。図中の $N=0 \%$ お よび $N=100 \%$ はそれぞれ逆極性加工, 正極性加 工の場合を示している。また，それぞれの記号 は逆極性放電の回数を表している。例えば, $N=$ $50 \% に お け る \square の$ 記号は正極性放電回数 10 回, 逆極性放電回数10回ずつの加工の結果を表して いる。図より明らかなように全放電回数に対す る正極性放電回数の比率 $N$ が， 0 から $50 \%$ に増 加するまでは加工速度は徐々に減少し，50\%を 越えると急激に増加する。そして $80 \%$ 付近で極

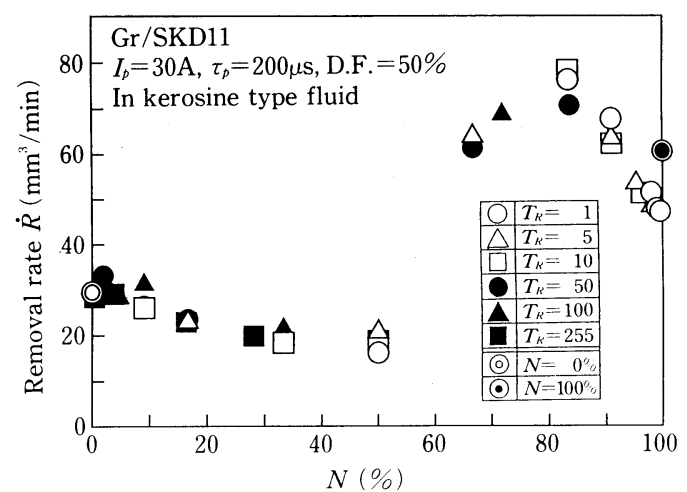

図 5 加工速度と正極性放電回数の比率 $N$ の 関係 (灯油系加工液) 
大値をもつ。つまり加工速度は, 正極性で加 工を行った場合（ $N=100 \%)$ よりあ正極性加 工に少し逆極性放電をおりまぜた場合のほう が大きくなることがわかる。これは正極性加 工において加工の妨げとなる何らかの要因が, 逆極性放電をおりまぜることによって改善さ れたためと考えられる。また，Nが50\%程度 までは加工速度は小さくなるが， $N=50 \% に$ おける值は逆極性加工（ $N=0 \%)$ の半分程 度である。さらに, これらの傾向は正極性放 電回数および逆極性放電回数にはほとんど左

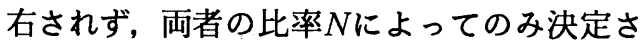
れることがわかる。すなわち，正極性放電 1 回と逆極性放電 1 回の組み合わせの加工でも, 正極性放電100回之逆極性放電100回の組み合 わせの加工でも（ $N=50 \%$ の場合), ほぼ同程 度の加工速度となっている。

図 6 は，加工液に脱イオン水を用いた場合 の加工速度 $R$ と N関係を示している。灯油系 加工液を用いた場合とは異なり，加工速度は， $N=0 \%$ から $N=100 \%$ までほぼ直線的に変化 する。つまり, 加工速度の值は放電痕除去体 積の大きい正極性放電と, 除去体積の小さい 逆極性放電との回数の割合のみで決定されて いるといえる。脱イオン水の場合は，灯油系 加工液の場合のように熱分解炭素生成物は生 じないことから考慮すると，前図の $N$ 対す る加工速度の特異な変化は以下のように推察 される。すなわち先ほど示したように，灯油 系加工液の場合 $N=80 \%$ 程度で加工速度が最 大となるのは，工作物表面の加工を妨げる炭 化層や熱分解生成物の層が一定の割合で逆極

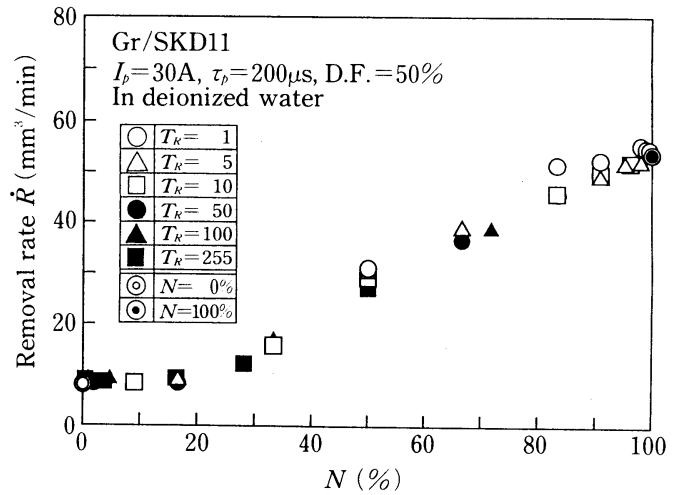

図 6 加工速度之正極性放電回数の比率 $N$ 関係 （脱イオン水）

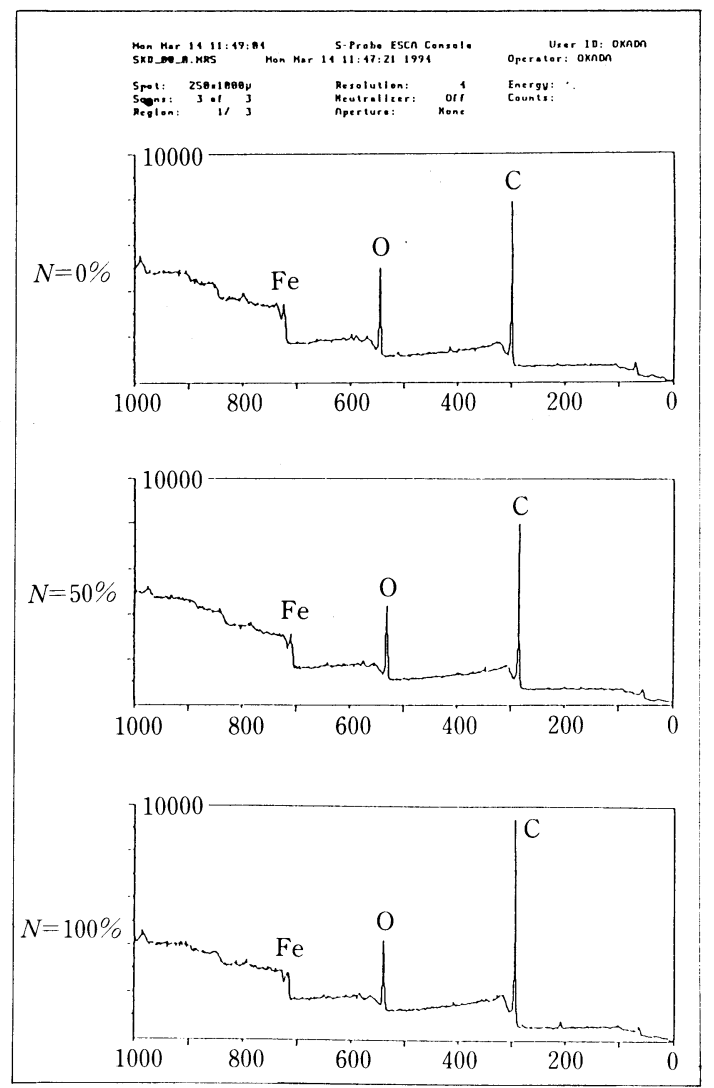

$\mathrm{Gr} / \mathrm{SKD} 11, I_{p}=30 \mathrm{~A}, \tau_{p}=200 \mu \mathrm{s}, \mathrm{D} . \mathrm{F}=50 \%$, In kerosine type fluid

図 7 工作物表面のXPS分析(イオンエッチング前) 


\section{Vol.29 No.60}

性放電をおりまぜることによって取り除かれたのではないかと考えられる。また $N=50 \%$ 付近までは 加工速度が逆極性加工よりあ小さくなるのは, 頻繁な極性の反転によって熱分解した炭素生成物が工 作物および電極に付着, 除去を繰り返すために加工が不安定となるためではないかと考えられる。

\section{3 加工面のXPS分析}

上記の推論を確かめるため, 灯油系加工液中で加工した工作物SKD11表面のXPS分析を行った。 その結果を図 7 に示す。グラフの横軸は分子の結合エネルギを示しており，それぞれピークは右から 炭素, 酸素および鉄である。これより, 加工表面にはいずれの場合あ炭素, 酸素の存在か碓認できる。 しかし工作物表面には加工後のコンタミネーションによる酸化層や炭化層が存在すると考えられる。 この加工最表面の污染層を取り除くために，アルゴンイオンで10分間イオンエッチングを行った。エッ チング条件は $2.5 \mu \mathrm{A} ， 5 \mathrm{KeV}$ である。このエッチングによって約 $500 \mathrm{~nm}$ の表面除去が行われた（ 3 次元表面構造解析顕微鏡ZYGO New View 100によって確認)。エッチング後のXPS分析の結果を図 8 に示す。エッチング前と比較すると素地の 鉄の強度が大きくなっていることが確認でき る。いっぽう酸素のピークは小さくなってお り, 表面の酸化層が取り除かれたと考えられ る。しかし, イオンェッチング後あ炭素およ び酸素が存在していることがわかる。工作物 として用いたSKD11にはもともと $1.4 \%$ の炭素 が含まれているが，その割合はNの変化には 無関係であると考えられる。しかし図より正 極放電回数の比率 $N$ 変化によって炭素, 酸 素の量は異なっていることがわかる。

図 9 は先ほどのXPS分析によって得られた 加工表面の炭素, 酸素のピーク値の正極性放 電回数の比率 $N に$ 対する変化を示すすのであ る。図中, 実線はイオンエッチング前, 破線 はイオンエッチング後の值である。また,

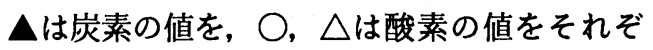
れ表している。図より明らかなようにエッチ ング後の場合， $N=0$ ～80\%までは酸素，炭 素ともNの変化に対しほとんど変化していな いが, $N=100 \%$ すなわち正極性加工の場合に

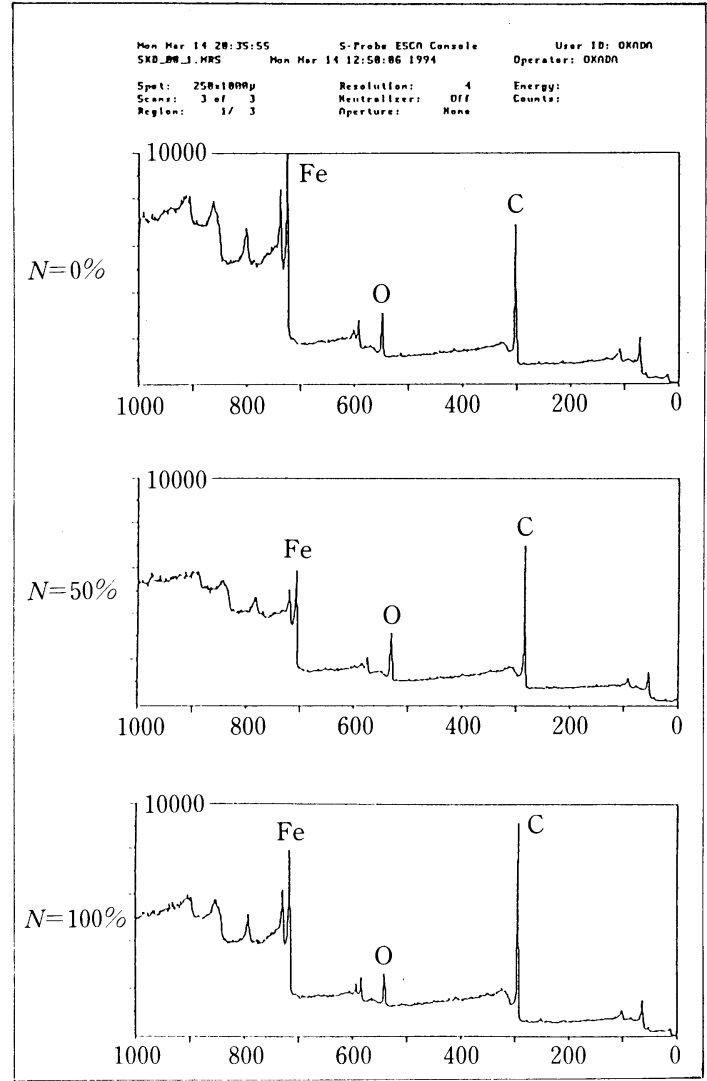

$\mathrm{Gr} / \mathrm{SKD} 11, I_{p}=30 \mathrm{~A}, \tau_{p}=200 \mu \mathrm{s}, \mathrm{D} . \mathrm{F}=50 \%$, In kerosine type fluid

図 8 工作物表面のXPS分析(イオンェッチング後) 
は炭素が増加し, 酸素が減少している。この 傾向はエッチング後も同様である。このこと より, 正極性放電のみの加工では, 加工表面 に熱分解炭素生成物の層あるいは炭化層が形 成されていると考えられる。そしてこの層を 逆極性放電によって除去することで前述のよ うに加工速度が增加するすのと考えられる。

\section{4 電極消耗および加工面粗さ}

図10は正極性放電回数の比率 $N$ 変化に対 する, 電極消耗率Wの值を示したものである。 これより, 電極の消耗率はNの増加とともに 増加することがわかる。 $N=0 \%$ の場合すな わち逆極性加工は電極無消耗加工の条件となっ ていることがみてとれるが, $N=30 \%$ 程度ま では電極消耗はマイナスの值を示しており， わずかに正極性加工をおりまぜてす電極無消 耗加工が可能であることがわかる。さらに， 加工速度の場合之同様に電極消耗率は, それ ぞれの放電回数には無関係で正極性放電回数 の比率Nのみによって決定されている。

図11は加工後のグラファイト電極端面のSE $\mathrm{M}$ 写真である。図より明らかなように $N=0$ \%すなわち逆極性加工の場合のグラファイト

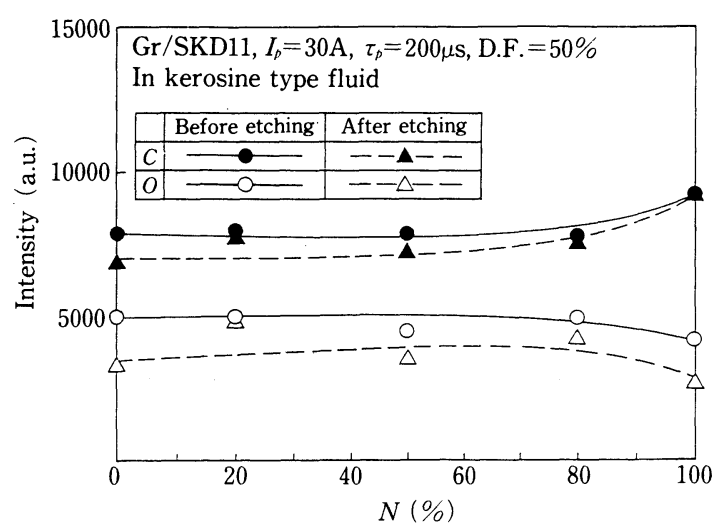

図 9 炭素および酸素の強度と正極性放電回 数の比率Nの関係

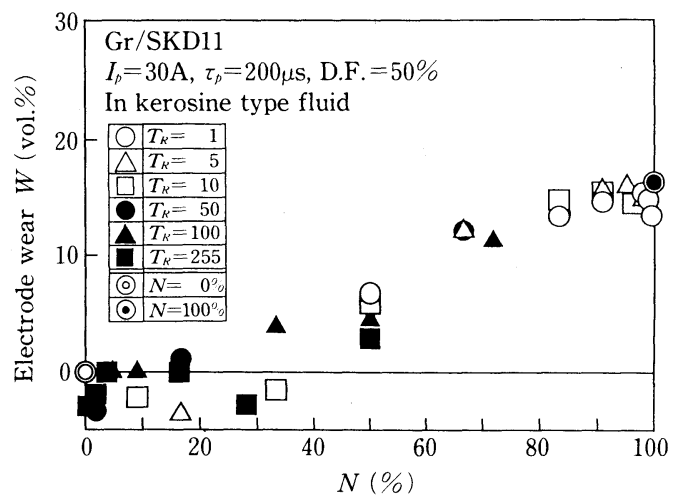

図10 電極消耗率と正極性放電回数の比率 $N$ の関係

電極端面には, 工作物の再凝固物および加工液の熱分解生成物の付着が全面にわたり認められる ${ }^{6)}$ 。 $N=20 \%$ すなわち逆極性加工に少し正極性放電をおりまぜた加工を行った後の工具電極端面にす工作 物および炭素生成物の付着が認められるが, 一部にグラファイト電極の面が円形に露出しているとこ ろも見られる。これは端面の付着物が正極性放電によって除去された痕跡であると考えられる。そし て, 正極性加工の割合が増加するにつれてグラファイト端面の露出の割合が多くなっている。さらに 正極性放電の割合が多い $N=80 \%, N=100 \%$ の場合には付着物はほとんどみられなくなる。電極無 消耗加工は工作物および炭素生成物の電極端面への付着によって実現されるわけであるが, 図にみら れるような電極端面への工作物および熱分解生成物の付着量は, 先ほどのNに対する電極消耗率の変 化とよく対応していることがわかる。 


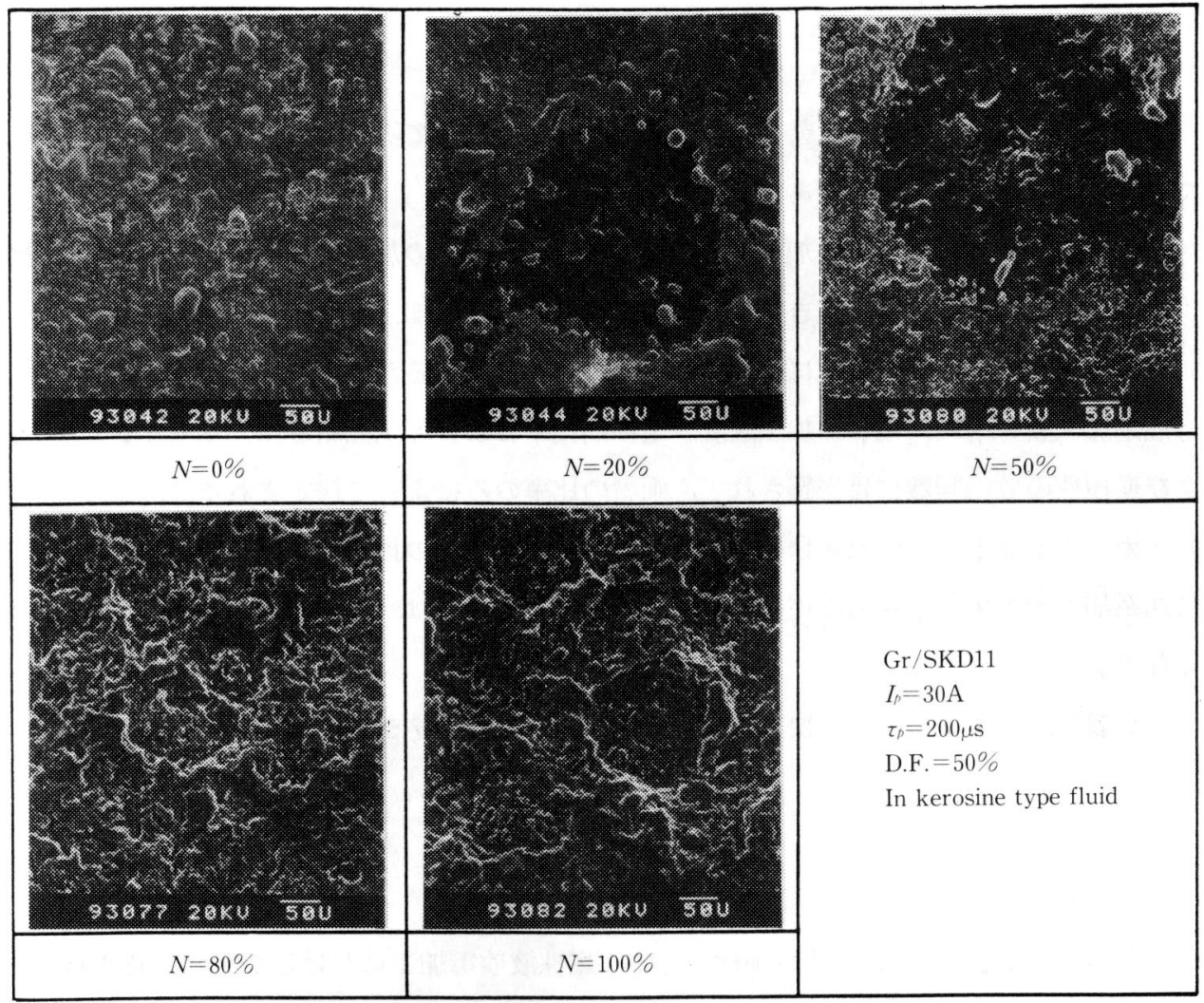

図11 電極端面SEM写真

図12は, 正極性放電回数の比率 $N$ の変化に対 する加工面粗さ $R_{\max }$ を示すすのである。これよ り, 加工面粗さは $N=0 \%$ $\%$ か $N=50 \%$ 程度まで はほぼ一定でその後Nの増加ととあに緩やかに 増加していることがわかる。前述の単発放電実 験で示したように，逆極性放電によるクレータ は正極性放電のクレータよりあ放電痕深さが小 さいため, 逆極性放電の割合が多い場合には正 極性放電での粗い加工表面を逆極性放電によっ ていくらか平滑にする作用があると考えられる。 また, 加工速度, 電極消耗率と同様, 加工面粗 さの値も正極性放電回数の全放電回数に対する

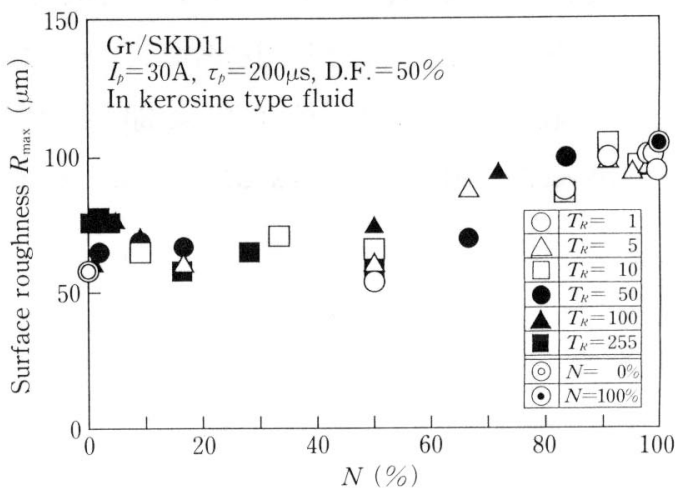

図12 加工面粗さと正極性放電回数の比率 $N$ の 関係 
比率Nによってのみ決定されていることがわかる。

\section{4. 結 論}

本研究では加工中に極性を切り替えた場合の加工特性について実験的に検討を行った。本研究で得 られた主な結論は以下のとおりである。

（1）灯油系加工液を用いた場合の加工速度は, 正極性放電のみの加工より 正極性放電に逆極性放電 を少し混合した場合のほうが大きい。これは，正極性のみの加工で形成された加工表面の炭化層あ るいは熱分解炭素を逆極性放電によって取り除くことができるためである。

（2）灯油系加工液を用いた場合の加工速度, 電極消耗率および加工面粗さは，1サイクル中の正極性 および逆極性の放電回数には影響されず，両者の比率のみによって決定される。

（3）脱イオン中で加工を行った場合の加工速度は，正極性放電の比率に対して直線的に増加する。

（4）灯油系加工液を用いた場合の電極消耗率および加工面粗さは，正極性放電の比率が大きいほど大 きくなる。

最後に実験を遂行するにあたり便宜を図っていただいた(株)ソディックに感謝いたします。

\section{参考文献}

1）後藤昭弘, 和田光悦, 尾崎好雄, 小林和彦: 不燃性液放電加工における加工面品質の向上, 電気 加工技術, 17, 57 (1993) 27.

2）宇野義幸, 中島利勝, 岡田 実: 水中放電加工に関する基礎的研究, 電気加工学会誌, 26,53 (1992) 55.

3）斉藤長男 : 放電加工のしくみと100\%活用法, 技術評論社(1979） 56.

4）本木康雄 : 電気・電子応用精密加工, オーム社(1982) 17.

5）宇野義幸, 岡田 晃 : 難削材料の高能率放電加工, 電気加工技術, 17, 55 (1993） 22 .

6）宇野義幸, 岡田 晃: 水放電に関する基礎的研究, 電気加工技術, 17, 57 (1993) 24 .

(1994年11月10日受付) 